Beata Karpińska-Musiał

Uniwersytet Gdański

https://orcid.org/0000-0001-5171-9224

lingbet@ug.edu.pl

Izabela Orchowska

Uniwersytet im. Adama Mickiewicza, Poznań https://orcid.org/0000-0003-0239-6160

izaorch@amu.edu.pl

\title{
MIĘDZYKULTUROWOŚĆ JAKO PRZESTRZEŃ DLA TRANSDYSCYPLINARNEJ METAANALIZY W GLOTTODYDAKTYCE I PEDAGOGICE MIĘDZYKULTUROWEJ - POLA WSPÓt-/ NIEZALEŻNOŚCI POJĘĆ, PARADYGMATÓW I CELÓW KSZTAŁCENIA
}

Interculturality as space for transdisciplinary meta-analysis in glottodidactics and intercultural pedagogy - inter-/in-dependence of concepts, paradigms and teaching aims

The paper presents a critical reflection on the issue of transdisciplinarity in defining interculturality as an object of scientific cognition on glottodidactics and intercultural pedagogy. Specifically, the authors propose a comparative meta-analysis of conceptualization of terms and paradigms, as well as teaching aims connected with interculturality in these two disciplines. They pose the question whether the transdisciplinary orientation is appropriate for scientific modeling and for defining teaching objectives on the borderline between interculturality in glottodidactics and intercultural pedagogy.

Keywords: transdisciplinarity, interculturality in glottodidactics, intercultural pedagogy, intercultural competence, co-culture

Słowa kluczowe: transdyscyplinarność, glottodydaktyczny obszar międzykulturowości, pedagogika międzykulturowa, kompetencja międzykulturowa, współkultura 


\section{Wprowadzenie}

Współcześni naukowcy, zwłaszcza w obszarze nauk społecznych i humanistycznych, stoją przed wyzwaniem nieustannego redefiniowania przedmiotu poznania reprezentowanych przez siebie dyscyplin naukowych. Dzieje się to często na drodze dialogu inter- $\mathrm{i}$ transdyscyplinarnego z naukami pokrewnymi, które odnoszą się do mniej lub bardziej tożsamych obszarów rzeczywistości empirycznej. W przypadku glottodydaktyki jest to zadanie szczególnie trudne. Z jednej strony jest to nauka ciągle aspirująca do autonomii poznawczej (epistemologicznej) i instytucjonalnej (zob. Dakowska, 2014, Orchowska, 2019 w opracowaniu), co wymaga zdefiniowania jej przedmiotu poznania w tylko jej specyficzny sposób. $Z$ drugiej strony ten przedmiot poznania jest na tyle złożony, że jego pogłębione zrozumienie wymagałoby zaznajomienia się również z wiedzą z obszaru nauk pokrewnych, których lista ciągle się wydłuża. Nie są to już tylko językoznawstwo, antropologia kultury, psychologia, pedagogika, socjologia wiedzy czy filozofia języka, ale także neurobiologia, neurodydaktyka, a nawet dynamicznie rozwijające się badania w obszarze cyfryzacji i nowych technologii. O poszerzaniu perspektywy w naukowym postrzeganiu i wyjaśnianiu rzeczywistości trzeciego millenium świadczy wkraczająca w dyskurs naukowy koncepcja konsiliencji, mówiąca wręcz o zapożyczaniu od siebie koncepcji i ramifikacji pojęć pomiędzy odległymi od siebie dziedzinami nauk (Chrzanowska-Kluczewska, 2016).

Uznając pełną zasadność koncepcji glottodydaktyki jako nauki aspirującej do autonomii (Dakowska, 2014), jak i argumentu jej interdyscyplinarnego charakteru (Komorowska, 2010; Karpińska-Musiał, 2015), w niniejszym artykule skupimy się na kwestii transdyscyplinarności przedmiotu poznania w glottodydaktycznym obszarze międzykulturowości w porównaniu z pedagogiką międzykulturową. Takie ukierunkowanie naszej refleksji wynika z przeświadczenia, że w sytuacji, gdy w polskiej i światowej humanistyce idea transdyscyplinarności staje się coraz bardziej popularna (Kita, 2012; Narcy-Combes, 2018) również glottodydaktycy i pedagodzy powinni zabrać głos w tej kwestii. Podejście transdyscyplinarne wydaje się umożliwiać obiecujące ujęcie międzykulturowości jako zjawiska będącego przedmiotem poznania zarówno w polskiej glottodydaktyce, jak i pedagogice ogólnej. Mamy tu bowiem do czynienia z wielce rozległą i złożoną materią, co dodatkowo komplikuje epistemologiczne sytuowanie się glottodydaktyków i pedagogów podejmujących problematykę (między)kulturową w swoich badaniach oraz obliguje ich do uporządkowania pojęć własnych i zapożyczanych z nauk pokrewnych. Równie istotne jest sformułowanie celów kształcenia odnośnie do rozwijania kompetencji międzykulturowej w obu dyscyplinach, z uwzględnieniem specyfiki danego kontekstu kształcenia jako integralnej części układu glottodydaktycznego (Pfeiffer, 2001: 21) 
Międzykulturowość jako przestrzeń dla transdyscyplinarnej metaanalizy...

oraz ogólnopedagogicznego. Warto w tym miejscu podkreślić wyższy poziom ogólności celów w pedagogice, a także ich „podatność” na ideologizację, co bez wątpienia nie może pozostać bez wpływu na definiowane na gruncie pedagogiki koncepcje kształcenia międzykulturowego.

Samo pojęcie transdyscyplinarności rozumiemy szeroko za J. Piagetem (1972, netografia) jako najbardziej zaawansowany etap relacji pomiędzy dyscyplinami naukowymi, który sprowadza się do wypracowania ogólnej teorii systemów i zaniku granic pomiędzy nimi, a jednocześnie pozwala na konceptualizację pojęć transwersalnych i siatki powiązań pomiędzy tymi pojęciami. Powinno to prowadzić do przedefiniowania celów poznawczych poszczególnych dyscyplin, jak i celów aplikacyjnych, które w przypadku glottodydaktyki i pedagogiki odnoszą się do celów kształcenia. Kolejnym krokiem byłoby wypracowanie nowej metodologii badawczej warunkującej badania prowadzące do realizacji przeformułowanych celów poznawczych i aplikacyjnych.

Aby pojęcie transdyscyplinarności nabrało właściwej ostrości warto skonfrontować je z pojęciem interdyscyplinarności, które za M. Dakowską (2014: 139) definiujemy jako „właściwość większości dziedzin współczesnych badań naukowych, która polega na podejmowaniu zagadnień wykraczajqcych poza granice przedmiotu pojedynczych dyscyplin". Interdyscyplinarne podejście do przedmiotu poznania będzie miało walor wzbogacający dopiero wówczas, gdy konstrukty powstałe poza daną dziedziną zostaną zaadoptowane do jej specyfiki epistemologicznej. Jak podkreśla W. Wilczyńska (2010: 28), by dane badanie mogło wpisać się w obszar glottodydaktyki, "winno ono być spójne wewnętrznie, tzn. formułować swój przedmiot, cele i wnioski właśnie w kategoriach glottodydaktycznych. Jest to niejako wstępny warunek (choć nie jedyny), by podjqć adaptację konstruktów pochodzqcych z innych dziedzin". Oczywiście przy wypracowywaniu pojęć i paradygmatów transwersalnych niezbędne jest zachowanie spójności przedefiniowanych wspólnie treści i ujęć.

Powodem, dla którego odnosimy się w niniejszej dyskusji do glottodydaktyki oraz pedagogiki międzykulturowej jest fakt, że obie te dyscypliny obejmują współcześnie swym przedmiotem poznania komunikacyjną i transakcyjną działalność człowieka zanurzonego w hiperprzestrzeni językowej, w której stykają się różne światy kulturowe przy różnych parametrach fizykalności (np. przestrzeń komunikacji wirtualnej). Przy zacieraniu się granic fizyczności kształcenia i komunikacji wskutek tworzenia się społeczności wirtualnych oraz wynikającej z tego faktu komunikacji z przedstawicielami różnych kultur na zasadach horyzontalnego, niezhierarchizowanego kontaktu, nowego znaczenia nabiera nie tylko komunikacja międzykulturowa, ale inaczej też przebiega definiowanie kompetencji międzykulturowej jako istotnego celu i czynnika kształcenia w obszarze glottodydaktyki i pedagogiki (zob. Rada Europy, 2003; Jaskuła i 
Korporowicz, 2017). Właśnie kompetencję międzykulturową, ze względu na złożoność tego terminu, obierzemy jako przedmiot przykładowej metaanalizy porównawczej na poziomie konceptualizacji pojęć w naszym artykule.

\section{Glottodydaktyka i pedagogika wobec współczesnej komunikacji międzykulturowej}

Badacze przełomu XX i XXI wieku definiowali pojęcia odnoszące się do zjawiska międzykulturowości, posługując się często odmiennie terminologią dotyczącą elementów składowych komunikacji międzykulturowej w glottodydaktyce oraz pedagogice międzykulturowej. Odzwierciedlają ten fakt chociażby znaczenia przypisywane przedrostkom „inter-", „między-" czy też "trans-" lub „cross-" i "meta-" umieszczane przed przymiotnikiem „kulturowy” (zob. np. Wilczyńska, 2005; Bourse, 2008; Puren, 2019; Nikitorowicz, 2009). Jeszcze inne rozbieżności terminologiczne i konceptualne zauważamy, porównując między sobą kierunki badań w obrębie bliskich sobie dyscyplin naukowych, takich jak: antropologia pedagogiczna oraz pedagogika antropologiczna (np. Ablewicz, 2003; Folkierska, 1990), socjolingwistyka, komunikologia (Puppel, 2007), wreszcie i sama filozofia dialogu w ujęciu np. przykładowo Martina Bubera lub Emmanuela Levinasa. Już choćby ta, niekompletna wszak, lista dyscyplin uwikłanych w interpretacje znaczeniowe międzykulturowości uwidacznia swoisty patchwork złożony z różnych dyscyplin nauk społecznych i humanistycznych.

Sytuując refleksję nad transdyscyplinarnością na pograniczu pedagogiki i glottodydaktyki, musimy pamiętać, że o ile ta pierwsza już dawno uzyskała instytucjonalny status nauki autonomicznej, to glottodydaktyka, ze względu na jej węższy zakres, raczej nie aspiruje do porównywalnego statusu. Jednocześnie, choć glottodydaktyka została pominięta w najnowszej klasyfikacji dyscyplin naukowych, co niejako kwestionuje jej autonomię instytucjonalną, to wielu badaczy wciąż podkreśla potrzebę ugruntowania się jej autonomii poznawczej. Co więcej, w polskim dyskursie metaglottodydaktycznym glottodydaktykę i jej autonomię poszczególni specjaliści definiują w sposób bardzo odmienny, określając ją jako naukę autonomiczną (Zając, 2010) lub dopiero aspirującą do autonomii (Dakowska 2014; Wilczyńska, 2010; Orchowska, 2019 w opracowaniu). Wilczyńska i Michońska-Stadnik (2010) uważają, że wypada ją usytuować na pograniczu nauk humanistycznych i społecznych, podkreślając jej swoistą, wyjątkową rangę pomostową. Jednocześnie wielu polskich anglistów postrzega kwestię autonomii epistemologicznej jako mało istotną dla sfery nauczania-uczenia się i użycia J2, i posługuje się terminem ,jjęzykoznawstwa stosowanego" w znaczeniu bardzo zróżnicowanej metodologicznie dziedziny interdyscyplinarnej, która czerpie z kilku źródeł wiedzy, m.in. z językoznawstwa, psychologii, socjologii, pedagogiki i nauk o komunikacji (zob. Niżegorodcew, 2009; 
Karpińska-Musiał, 2015). Wśród germanistów z kolei są specjaliści (np. Pfeiffer, 2010; Jaroszewska, 2014), którzy uznają kwestie dyscyplinarne za drugorzędne, opowiadając się za poszerzeniem profilu badawczego dziedziny w celu wyjścia naprzeciwko praktyce, m.in. poprzez dostrzeżenie większej roli pedagogiki w badaniach glottodydaktycznych.

W kontekście tego wciąż aktualnego sporu o status glottodydaktyki jako nauki i o jej relacje z pedagogiką, pojawiają się dyskusje na temat aparatu pojęciowego i specyfiki pola poznawczego obu dyscyplin. Swoistym łącznikiem terminologicznym pomiędzy dziedzinami humanistycznymi i społecznymi stały się m.in. pojęcia kompetencji oraz kwalifikacji (bardziej instrumentalnie zorientowanych umiejętności konkretnych w wybranym obszarze zawodowym i badawczym; np. Szlosek, 2001). Przy tym, Wilczyńska (2016) zwraca uwagę na fakt, że w glottodydaktyce zwykle jest mowa o jednej, całościowej kompetencji komunikacyjnej $\mathrm{w} \mathrm{J1} \mathrm{i} /$ lub w J2. Ujęcie to opiera się na założeniu, że proces rozwijania kompetencji komunikacyjnej ma z natury rzeczy charakter podmiotowy, a tym samym wpisuje się w całościowy rozwój osoby uczącej się i funkcjonującej w JK2 na własną miarę. Z kolei w pedagogice przyjmuje się cały kompleks elementów, nazwanych międzykulturowymi kompetencjami komunikacyjnymi, które obejmują swoim spektrum komponenty nawiązujące bardziej do postaw i relacji wobec inności, aniżeli do samych komunikatów językowych (Nikitorowicz i in., 2013; Nikitorowicz, 2009: 293). Innymi słowy, perspektywa pedagogiczna zmierza do procesu konstytuowania człowieka w kulturze zdominowanej przez określone reguły społeczne, a glottodydaktyczna wspiera go w adekwatnych do tego celu zachowaniach komunikacyjnych.

Wobec powyższego, zaryzykować można stwierdzenie, że skoro w ujęciu glottodydaktycznym rozwój kompetencji komunikacyjnej dokonuje się na bazie preferowanych przez podmiot (jednostkę) postaw i zachowań językowych w powiązaniu z jego systemem wartości i doświadczeniami komunikacyjnymi oraz edukacyjnymi, a w pedagogice owa kompetencja jest osadzona bardziej cywilizacyjnie i historycznie, będąc przy tym uwarunkowaną polityczno-kulturowymi wyborami, inna będzie też semantyka znaczeń przypisywanych pojęciom świadomości i kompetencji (np. kulturowej, międzykulturowej, językowej, językoznawczej, metajęzykoznawczej).

Dodatkowo, ujęcie pedagogiczne wpisuje się w transformację samej esencji komunikacji (oraz kompetencji) międzykulturowej, którą uznaje się za kluczowy obiekt praktyki oraz badań niezależnie od współczesnych zmian w przestrzeni dostępnej do praktykowania dialogu. Mamy tu na myśli transgresję pomiędzy światem realnym, za jaki można uznać komunikację naturalną z Innym oraz tę symulowaną w klasie językowej, a światem hipertekstu i wirtualnej rzeczywistości (np. w ramach społeczności budowanych w mediach społecznościowych oraz 
ogólnie w sieci; zob. Braidotti, 2014). Z kolei w ujęciu glottodydaktycznym nie chodzi o transformację esencji komunikacji międzykulturowej, ale postuluje się raczej taki rozwój kompetencji międzykulturowej, w którym kluczową rolę odgrywałby „świadomy wgląd w istotę i tryb działania kultury-w-nas w wymiarze indywidualnym i interpersonalnym (interpsychicznym). Wgląd taki mógłby dalej znakomicie wspomóc naszą wrażliwość i świadomość nie tylko kulturową, ale wręcz kulturowościową" (Wilczyńska, Mackiewicz \& Krajka, 2019: 122). Tym samym, kompetencja interkulturowa byłaby praktykowana jako tzw. kulturowe pogranicze-w-nas (ibidem: 375), a w konsekwencji zbliżałaby się do tego, jak bywa rozumiana kompetencja transkulturowa i metakulturowa (ibidem: 123).

Należy jednocześnie uwzględnić fakt, że problematyka komunikacji międzykulturowej nabiera wobec włączenia w społeczne funkcjonowanie człowieka cyberprzestrzeni jako zupełnie nowego wymiaru, znacznie szerszego znaczenia w stosunku do okołomilenijnych koncepcji pedagogiki i teorii krytycznej końca XX stulecia. Ta ostatnia pouczała o sile różnicy, o specyfice Innego, który aksjologicznie różnił się od Ja i przebudowywała tożsamość interlokutorów w kierunku postulowanych zmian społeczno-politycznych lub kulturowych. Komunikacja międzykulturowa była komunikacją językową z innym systemem znaków, innymi symbolami oraz inną kulturą, która wymagała dążenia do porozumienia, a przynajmniej zrozumienia różnic i powodów nieporozumień w głównie realnej komunikacji językowej, za jaką uznaje się zarówno kontakt z Innym w przestrzeni geofizycznej, jak i w klasie językowej poprzez symulację komunikacji obcojęzycznej (np. Karpińska-Musiał, 2015; Aleksandrowicz-Pędich, 2005; Byram \& Risager, 1999). Kompetencja międzykulturowa rosła więc wprost proporcjonalnie do językowo-kulturowej, wzbogacana o elementy metajęzykoznawczej świadomości jednostki w zakresie pragmatyki komunikacji oraz kompetencji określanych jako proteofiliczne (Karpińska-Musiał, 2015).

Tymczasem cyberprzestrzeń ostatnich dwóch dekad nowego millenium zaskoczyła nas zupełnie nową socjologią komunikacji międzykulturowej. Jak piszą Jaskuła i Korporowicz (2017: 35), dialog w wymiarze wirtualnym nadal jest dialogiem, gdyż „[w]ielość i łatwość spotkań zachodzących w nowym wymiarze generują potrzeby wzajemnego zrozumienia, które jest możliwe nie tyle na drodze rozmowy, ile właśnie dialogu. Dialog bowiem wykracza poza postawy przekonujące do swoich racji, a staje się poszukiwaniem prawdy, również poprzez modyfikowanie własnych przekonań". Stąd też autorzy ci posługują się pewnymi kryteriami dialogu sokratejskiego, które stanowią dla nich niejako matrycę kategorii porównawczych dla dialogu tradycyjnego i tego przeniesionego w przestrzeń wirtualną. Przywołują tutaj, jako przykłady „koncepcję Agory, odniesienie egzystencjalne, brak dogmatyzmu, majeutykę, poszukiwanie prawdy, samodzielność rozumu i myślenie w grupie" (Jaskuła i Korporowicz, 
2017: 36-37). W każdej z tych kategorii realizuje się dialog, pomimo przepaści w uwarunkowaniach pomiędzy starożytną fizykalnością kontekstu dialogu sokratejskiego (spacery po agorze) a współczesną jego wirtualizacją (w przestrzeni świata cyfrowego). Przy spełnianiu jednak jednego istotnego warunku: chęci do osiągnięcia porozumienia wskutek myślenia racjonalnego i procesu raczej akulturacji niż dekulturacji.

Z drugiej strony, ci sami autorzy twierdzą, że: „[w]śród wielu problemów nierozpoznanych $w$ przestrzeni wirtualnej na uwagę zasługuje zagadnienie obecności człowieka w świecie bez granic", gdzie określenia zjawisk, procesów i działań wiążących się z konkretnym terytorium tracą sens" (Jaskuła i Korporowcz, 2017: 38). I tak, jak wirtualna rzeczywistość pozwala na dehierarchizację, na bazowanie na doświadczeniu, na wolność osądów i dochodzenie do konstruktywnych wniosków wspólnych, tak jednak rodzi też inne skutki: odrzucenie dialogu lub aporetyczną konkluzję o niemożności dojścia do porozumienia (Karpińska-Musiał, 2015). By komunikacja międzykulturowa zaistniała w cyberprzestrzeni, zdolność do „zrozumienia, dlaczego do porozumienia nie dochodzi" wydaje się być warunkiem sine qua non kompetencji międzykulturowej. Podobnie jak, zgodnie z tym, co twierdzą wyżej cytowani autorzy, jest nim to, by rozumieć komunikację w kategorii między-, a nie inter- lub wielokulturowości. Przedrostek między- kierunkuje komunikację, zdaniem ww. autorów, bardziej na obopólność i wielokierunkową wzajemność, aniżeli na jednopłaszczyznową wymianę określaną przedrostkiem inter-. Bardziej czytelnego rozróżnienia w kontekście kontaktów kultur dokonuje tutaj MikułowskiPomorski (2006), który przytacza za Sitaram i Cogdell (1976) przedrostek mię$d z y$ - w znaczeniu poprzez- (cross-) dla określenia etnicznego uwarunkowania badań porównawczych między kulturami, pozostawiając inter-porównaniom kultur na poziomie przynależności do grup społeczno-językowych i profesjonalnych (Speech Communities). Czy jednak, wracając do kontekstu czysto komunikacyjnego, na pewno jest tak, że dialog wirtualny zmierza do osiągania transgresji i wpływu wzajemnego? Gdyby tak było w istocie, a potwierdzają to coraz liczniejsze badania i studia z zakresu intencyjności komunikowania medialnego w przestrzeni cyfrowej, to z pewnością zmienił się styl i wielokierunkowość tej komunikacji (por. np. Tanaś i Galanciak, 2018).

\section{Kryteria różnicowania w glottodydaktycznym obszarze międzykulturowości i na gruncie pedagogiki międzykulturowej}

Proponowana próba poszukiwania współ- lub niezależności na poziomie metaanalizy obszarów glottodydaktyki i pedagogii międzykulturowej będzie dotyczyła obranych wcześniej kryteriów: konceptualizacji pojęć w dyskursie naukowym z 
obu dyscyplin, dominujących paradygmatów oraz celów kształcenia. Tym samym, postaramy się odpowiedzieć na pytanie, czy pedagogika międzykulturowa jako nauka społeczna oraz glottodydaktyka jako nauka pogranicza, badająca z jednej strony procesy komunikacyjne i relacje społeczne, a z drugiej strony świadomość uczestników nauczania-uczenia się $\mathrm{J} 2$ i ich procesy interpretacyjne (Wilczyńska i Michońska-Stadnik, 2010: 18), mogą w obszarze międzykulturowości funkcjonować jako uprawniony, transdyscyplinarny system.

\subsection{Konceptualizacje pojęć - od ujęć dyscyplinarnych do pojęć transwersalnych}

Po wstępnym zasygnalizowaniu w punkcie 1 . terminologicznych dychotomii niektórych pojęć $w$ obu porównywanych naukach, proponujemy poddanie głębszej analizie porównawczej pojęcia kompetencji międzykulturowej. Konceptualizacja tego pojęcia w perspektywie obu nauk zilustrowana jest w zestawieniu poniżej (tab. 1).

\begin{tabular}{|c|c|}
\hline $\begin{array}{l}\text { Konceptualizacje kompetencji międzykulturowej w glot- } \\
\text { todydaktyce }\end{array}$ & $\begin{array}{l}\text { onceptualizacje kompetencji } \\
\text { iędzykulturowej w pedagogice międzykulturowej }\end{array}$ \\
\hline $\begin{array}{l}\text { Kompetencja interkulturowa (transkulturowa) jest trakto- } \\
\text { wana jako zależna od postaw osoby uczącej się (m.in. po- } \\
\text { stawa otwartości, kontrola emocjonalna, postawa kry- } \\
\text { tyczna) i składają się na nią: } \\
\text { „- specyficzna świadomość metakulturowa (obejmująca } \\
\text { naturę i mechanizmy funkcjonowania kultury); } \\
\text { - wrażliwość (inter)kulturowa (pozwalająca rozpoznawać } \\
\text { przejawy działań kulturowych i doszukiwać się odpowied- } \\
\text { niej ich interpretacji); } \\
\text { - umiejętność mediacji interkulturowej (umożliwiająca } \\
\text { zrównoważoną interakcję nastawioną na usuwanie barier } \\
\text { komunikacyjnych i wzajemne wzbogacanie się)” (Wilczyń- } \\
\text { ska, 2005: 22). } \\
\text { Świadomość metakulturowa jako kluczowa dla budowania } \\
\text { kompetencji interkulturowej jest pewnego rodzaju świado- } \\
\text { mością kulturowości, która może zapewnić nam niezbędny } \\
\text { dystans do własnej kultury, a także dostarczyć ram pojęcio- } \\
\text { wych w konfrontacji z innością (Wilczyńska i in., 2019: 122). }\end{array}$ & $\begin{array}{l}\text { Kompetencje do komunikacji międzykulturowej } \\
\text { określa się jako kompetencje indywidualne, spo- } \\
\text { łeczne i kulturowe zależne od środowiska lokalnego i } \\
\text { poczucia więzi lokalnej, osobistych doświadczeń mi- } \\
\text { gracyjnych i doświadczeń w tym zakresie członków } \\
\text { rodzin oraz poczucia tożsamości kulturowej (Nikito- } \\
\text { rowcz i in., 2013). } \\
\text { Do takich kompetencji zalicza się też: } \\
\text { - otwartość na informacje o „Innych”, na dialog infor- } \\
\text { macyjny, w efekcie otwarcie tożsamościowe; } \\
\text { - dialog negocjacyjny, zdolność i umiejętność prowa- } \\
\text { dzenia dialogu jako imperatywu wzajemnego roz- } \\
\text { woju, zachowania i kształtowania pokoju; } \\
\text { - efektywne porozumiewanie się z partnerem inter- } \\
\text { akcji, symbioza kulturowa, umiejętność współżycia, } \\
\text { rozwiązywania problemów-konfliktów, wzajemne } \\
\text { wzmacnianie kulturowe (ibidem: 11). }\end{array}$ \\
\hline $\begin{array}{l}\text { Kompetencja międzykulturowa rozumiana jako „rodzaj } \\
\text { kompetencji, który umożliwia uczącym się działanie w sytu- } \\
\text { acjach kontaktu z innością kulturową: od postrzegania po- } \\
\text { przez interpretację tych sytuacji do tworzenia odpowied- } \\
\text { nich reguł działania” (Torenc, 2007: 203). Tak rozumiana } \\
\text { kompetencja międzykulturowa powinna stanowić istotne } \\
\text { narzędzie poznawcze oraz podstawę działania w kontakcie } \\
\text { z innością kulturową. Ta sama autorka przyjmuje, że to } \\
\text { „układ glottodydaktyczny jest jednym z możliwych ukła- } \\
\text { dów, w jakich podmiot działa na płaszczyźnie międzykultu- } \\
\text { rowej poprzez kontakt z innością kulturową” (Torenc, 2007: }\end{array}$ & $\begin{array}{l}\text { Międzykulturowa kompetencja komunikacyjna to: } \\
\text { zdolność do budowania pozytywnych stosunków } \\
\text { międzyludzkich w bezpośrednich kontaktach, do sku- } \\
\text { tecznej komunikacji dzięki nabyciu umiejętności ra- } \\
\text { dzenia sobie ze stresem, redukcji obaw negatywnego } \\
\text { odbioru, radzenia sobie z reakcjami i stygmatyzacją, } \\
\text { umiejętności analizy stereotypizacji, zdolności zaan- } \\
\text { gażowania i empatii, zdolności do zmiany punktu wi- } \\
\text { dzenia, stosunków emocjonalnych i relacji (Nikitoro- } \\
\text { wicz, 2009: 293). }\end{array}$ \\
\hline
\end{tabular}




\begin{tabular}{|c|c|}
\hline $\begin{array}{l}\text { 117), a przy rozpatrywaniu procesów kulturowych zacho- } \\
\text { dzących w układzie glottodydaktycznym, postuluje odwo- } \\
\text { łanie się do teorii subiektywnych uczącego się oraz jego } \\
\text { kompetencji. }\end{array}$ & \\
\hline $\begin{array}{l}\text { W glottodydaktycznym ujęciu wpisującym się w tzw. dy- } \\
\text { daktykę autonomizującą kompetencja międzykulturowa } \\
\text { osoby uczącej się J2 została zdefiniowana jako podkompe- } \\
\text { tencja wyróżniona w ramach jej osobistej kompetencji ko- } \\
\text { munikacyjnej, która wpływa na i znajduje się pod wpły- } \\
\text { wem takich jej komponentów, jak: kompetencja semio- } \\
\text { tyczna, referencyjna, dyskursywna, społeczno-językowa, } \\
\text { pragmatyczna i strategiczna (Orchowska, 2008: 148). }\end{array}$ & $\begin{array}{l}\text { W perspektywie pedagogicznej, międzykulturowa } \\
\text { kompetencja komunikacyjna to zgodność i spójność } \\
\text { komunikacyjna, zdolność do integracji społecznej, } \\
\text { wiedza o komunikujących się ze sobą kulturach, a } 7 \\
\text { składników potrzebnych do adaptacji wobec inności } \\
\text { to empatia, szacunek, elastyczność ról, orientacja na } \\
\text { wiedzę, postawa interakcyjna, kierowanie interak- } \\
\text { cyjne i tolerancja dla niejednoznaczności (za Kwieciń- } \\
\text { ski w: Nikitorowicz, 2009). }\end{array}$ \\
\hline $\begin{array}{l}\text { W końcu z metajęzykoznawczej perspektywy, model kom- } \\
\text { petencji międzykulturowej nauczyciela J-K2 uwzględnia } \\
\text { kompetencję metajęzykoznawczą pod nazwą treningu wie- } \\
\text { dzy metajęzykoznawczej, ale również włącza takie kompo- } \\
\text { nenty, jak: międzykulturowa kompetencja pragmatyczna², } \\
\text { kompetencje glottodydaktyczne i kompetencje pedago- } \\
\text { giczne, relacje pomiędzy nimi oraz autentyczność i zaanga- } \\
\text { żowanie (Karpińska-Musiał, 2015). }\end{array}$ & $\begin{array}{l}\text { Pedagodzy konstruując dalsze konceptualizacje mię- } \\
\text { dzykulturowej kompetencji zwracają jeszcze uwagę } \\
\text { na (wg modelu Lustiga, Koestlera, Martin i Stortiego): } \\
\text { tolerancję dla niejednoznaczności, elastyczność po- } \\
\text { znawczą i zachowań, tożsamość kulturową, cierpli- } \\
\text { wość, entuzjazm, zaangażowanie, umiejętności inter- } \\
\text { personalne, otwartość, empatię, szacunek i poczucie } \\
\text { humoru (w: Nikitorowicz, 2009). }\end{array}$ \\
\hline
\end{tabular}

Tabela 1: Pojęcie kompetencji międzykulturowej w ujęciach koncepcyjnych glottodydaktyków i pedagogów (opracowanie własne)

Porównanie ujęć koncepcyjnych pojęcia (komunikacyjnej) kompetencji międzykulturowej proponowanych przez polskich glottodydaktyków pokazuje, że glottodydaktyczny obszar międzykulturowości odnosi się do przedmiotu poznania o charakterze interdyscyplinarnym, a poszczególni specjaliści, definiując to pojęcie, odnoszą się do koncepcji wypracowanych poza ich dyscypliną, dostosowując je do epistemologicznej specyfiki jej ogólnego przedmiotu poznania. Dla przykładu, definicja kompetencji międzykulturowej zaproponowana przez M. Torenc (2007) wpisuje się w szeroko rozumianą edukację międzykulturową z obszaru pedagogiki i psychologii, podobnie jak przywołane przez nią teorie subiektywne. Współautorka niniejszego tekstu, B. KarpińskaMusiał (2015) także ujmuje w przywołanym modelu elementy przynależne do nauk pedagogicznych, szczególnie w obszarze postaw niezbędnych do wykazania

${ }^{1}$ Glottodydaktyczny paradygmat dydaktyki autonomizującej opiera się na założeniu świadomego dążenia do zwiększenia zakresu autonomii uczącego się poprzez włączenie go w ramach tzw. współpracy dydaktycznej w planowanie, organizację i ewaluację zadań uczeniowo-komunikacyjnych, których celem jest kształtowanie jego osobistej kompetencji komunikacyjnej (Wilczyńska, 2002b: 319).

${ }^{2}$ W ramach tej kompetencji autorka (Karpińska-Musiał, 2015: 125) wymienia kompetencję proteofiliczną, kompetencję funkcjonalną (pragmatyczną), kompetencje komunikacyjne, kompetencje metapragamtyczne, językowe i systemowe oraz kompetencję aksjolingwistyczną, kompetencje krajoznawcze i kulturoznawcze. 
kompetencji międzykulturowej. Z kolei I. Orchowska (2008) podkreśla specyfikę międzykulturowej kompetencji w J2 poprzez wskazanie na takie komponenty osobistej kompetencji komunikacyjnej, jak: kompetencja semiotyczna, referencyjna, dyskursywna, społeczno-językowa, pragmatyczna i strategiczna. Każda z nich jednocześnie wpływa na to, jak dany użytkownik języka komunikuje się, poprzez budowanie znaczeń właśnie w zakresie, (współ)konstruowania wiedzy i wyobrażeń o świecie, czy też w zakresie społecznych praktyk dyskursywnych oraz realizacji celów komunikacyjnych, przy większym lub mniejszym zaangażowaniu w przestrzeganie norm społeczno-językowych (Orchowska, 2008). Powyższe rozumienie kompetencji nie ogranicza się do sfery wyobrażeń użytkowników języka, ale obejmuje również ich wiedzę, postawy i wartości, działania komunikacyjne oraz szeroko rozumianą kompetencję do uczenia się, w tym zespół postaw, jakie przyczyniają się do definiowania celów uczenia się i oceny ich realizacji w zakresie budowania świadomości (meta)kulturowej. To ostatnie pojęcie definiuje Wilczyńska (2005) jako świadomość, obejmującą naturę i mechanizmy funkcjonowania kultury, podkreślając jednocześnie, że w komunikacji powinniśmy uwzględnić zróżnicowanie społeczne, a jednocześnie pamiętać o pewnym przenikaniu i wspótistnieniu wzorców i norm kulturowych. Współcześnie może to być szczególnie trudne, gdyż mamy do czynienia z coraz większą dowolnością, ale i szerszymi możliwościami w budowaniu przez poszczególne jednostki ich tożsamości kulturowej, chociażby w efekcie wspomnianej rewolucji cyfrowej i masowej komunikacji społecznej.

Nieco inaczej, ale wciąż w ramach perspektywy glottodydaktycznej, B. Karpińska-Musiał (2015) koncentruje się w swoim modelu na kompetencji metajęzykoznawczej. W takim ujęciu, „dopiero znajomość pojęć z zakresu metajęzyka w połaczeniu ze zrozumieniem ich funkcjonowania w skomplikowanym akcie komunikacyjnym gwarantuje pełniejszq możliwość negocjacji znaczeń lub diagnozowania kontekstualnych różnic w interpretacji" w sytuacji komunikacji międzykulturowej (Karpińska-Musiał, 2015: 114). Tym samym to właśnie uświadomiona wiedza metajęzykoznawcza stanowi bazę, dzięki której może zachodzić rozpoznanie i określenie inności, a także mediacja w zakresie wyjaśniania kulturowej odmienności tej inności w sytuacji nauczania J-K2. Ten aspekt buduje, zdaniem cytowanej autorki, swoisty pomost pomiędzy interpretacjami glottodydaktycznymi a pedagogicznymi w zakresie kompetencji międzykulturowej, gdyż nawiązuje do identyfikacji narzędzia otwierającego postrzeganie i budowanie postaw. Jak bowiem widać w konceptualizacjach pedagogów, pomimo iż terminologia często nawiązuje do komunikacyjnej kompetencji międzykulturowej, jej elementy składowe oscylują głównie wokół wartości oraz postaw umożliwiających adaptację do Innego lub przynajmniej tolerancję i zrozumienie inności w relacjach z Innym. Relacje te nie zawsze 
nazywane są i postrzegane stricte poprzez język, nabierając definicyjnie szerszego wymiaru i znaczenia. Są bowiem uwikłane w szerszy kulturowo-społeczny, antropologiczny i nierzadko ideologiczno-polityczny kontekst interpretacyjny. Co ważne, wyżej przywołane, przykładowe interpretacje odnoszą się także, podobnie jak w ma to miejsce w glottodydaktyce, do postaw i umiejętności oczekiwanych od nauczycieli w zakresie międzykulturowości, co pozwala potraktować je jako analogicznie ukontekstowione i wysuwać wnioski porównawcze co do praktycznych działań edukacyjnych w obu dyscyplinach.

Podsumowując, to, co łączy konceptualne ujęcia kompetencji międzykulturowej zaproponowane przez glottodydaktyków i pedagogów to z pewnością odniesienie do kultury jako integralnej części tożsamości człowieka, przy założeniu jej wielowymiarowości, dynamiki i ciągłego rozwoju. Jak pisze J. Nikitorowicz (2003: 202), kultura to „zjawisko społeczne, normatywne, historyczne, i pokoleniowo zmienne, symboliczne, funkcjonalne, strukturalne i psychologiczne" i dlatego powinno być rozpatrywane także z punktu widzenia jednostki i jej doświadczeń zakorzenionych w środowisku społecznym. Przy takim założeniu możemy zatem uznać kulturę za pojęcie transwersalne, podobnie jak świadomość metakulturowq, która powinna obejmować świadomość zjawisk kulturowych w ogóle, w tym świadomość semiotycznej natury kultur, pojęcie tzw. tożsamości wielorakiej ${ }^{3}$ oraz pojęcie świadomości metapoznawczej jako warunku odpowiedzialnego udziału osoby uczącej się w procesie kształcenia. Do takich pojęć można zaliczyć także kompetencję międzykulturową.

Co niesie wypracowanie pojęć transwersalnych odnoszących się do międzykulturowości i sytuujących się na granicy glottodydaktyki i pedagogiki w wymiarze poznawczym? Uważamy, że jest ono funkcjonalne dla epistemologicznego osadzenia badań transdyscyplinarnych, ukierunkowanych na lepsze rozumienie i opisanie kontekstu kształcenia międzykulturowego w Polsce. Na uwagę zasługuje tutaj konieczność uwzględnienia specyfiki polskiego społeczeństwa pod względem podchodzenia poszczególnych jednostek do zjawiska międzykulturowości, konstruowania własnej tożsamości i mechanizmów komunikacji międzykulturowej, w tym globalnej komunikacji wirtualnej. Warto przy tym pamiętać, że współczesne społeczeństwa tzw. świata zachodniego cechuje znaczny stopień heterogeniczności (zob. Wilczyńska, 2005), co może czynić edukację międzykulturową coraz trudniejszą, pomimo zredukowania, czy nawet zlikwidowania dystansu geograficznego w związku z rewolucją technologiczną i medialną.

\footnotetext{
3 Tożsamość wieloraką rozumiemy za Wilczyńską, Mackiewiczem i Krajką (2019: 111) jako tożsamość wielopoziomową, której ten lub inny aspekt uaktywnia się w zależności od relacji i realizowanych celów lub funkcji.
} 


\subsection{Obszar paradygmatycznego osadzenia celów poznawczych w glottodydaktyce i pedagogice międzykulturowej}

Stawiamy tezę, że rewolucja cyfrowa, a ściślej globalny charakter oddziaływania medialnego, zmieniły świat dialogu międzykulturowego, wnosząc dużą dozę (do)wolności i przyczyniając się do autonomizacji każdego uczestnika komunikacji. Wywołało to w społeczeństwach poczucie upełnomocnienia i uprawomocnienia do głoszenia swoich poglądów, którym np. teorie komunikowania masowego przypisują rozmaite struktury związane z transmisyjnością, pośredniczeniem, interpelacyjnością oraz interpretatywnym charakterem odczytu komunikatów (informacji) obecnych w mediach. Komunikacja społecznościowa, z kolei, wymusiła więcej samokontroli (i odpowiedzialności), ale też umożliwiła odwrót od komunikowania się, gdy nie spełnia ono oczekiwań którejkolwiek ze stron. Tzw. nowe media uczyniły komunikację szybszą, natychmiastową (kultura instant), a jednocześnie zrodziły zjawisko badane przez socjologów jako „missing-out” - poczucie bycia wykluczonym i pominiętym w przepływie informacji. Towarzyszy temu osłabienie wspólnotowości i podzielania znaczeń w ramach funkcjonowania przedstawicieli danej kultury, przy czym paralelnie tworzą się inne rodzaje więzi i (po)rozumienia, np. pomiędzy osobami podzielającymi te same pasje lub poglądy polityczne, co widoczne jest chociażby w grupach społecznościowych budowanych na Facebooku.

Uwzględniając specyfikę współczesnego dialogu prowadzonego w cyberprzestrzeni, warto pochylić się nad definicją celów poznawczych, które odnosiłyby się do badania zjawiska międzykulturowości w glottodydaktyce i pedagogice. Musimy jednak uwzględnić tutaj rozbieżności epistemologiczne w definiowaniu i interpretowaniu pojęcia paradygmatu przez pedagogów i glottodydaktyków (por. Kwieciński, 2011; Dakowska, 2010), jak i odmienne osadzenie paradygmatyczne badań glottodydaktycznych i pedagogicznych.

I tak, w glottodydaktyce, $z$ racji jej nachylenia w kierunku językoznawstwa, przez długi czas za najbardziej operacyjny uchodził paradygmat strukturalistyczny, następnie również w jego odmianach granicznych z post-strukturalizmem oraz ilościowo zorientowaną metodologią badawczą. Współcześnie, jak zauważa M. Dakowska (2014), nastąpiło odejście od pojęcia reguły językowej, a pojęciem centralnym dla dydaktyki J2 jest „użycie języka”. Nie mamy już do czynienia z traktowaniem $J 2$ jako systemu formalnego, gdyż to uniemożliwiało uchwycenie społecznej $i$ indywidualnej zmienności zachowań komunikacyjnych uczącego się, a na poziomie dydaktyki prowadziło do pomijania kształcenia "specyficznych umiejętności i sprawności jako podstawy podmiotowo realizowanych działań komunikacyjnych" (Wilczyńska, 2010: 23). Dzisiaj za główną oś scalającą wysiłki poznawcze w obszarze glottodydaktyki można 
by uznać rozwój osobistej kompetencji komunikacyjnej (Wilczyńska, 2010), przy czym w praktyce dla znaczącej części polskich glottodydaktyków punkt odniesienia stanowi model kompetencji użytkownika J2 prezentowany w Europejskim Systemie Opisu Kształcenia Językowego (Rada Europy, 2003). W konsekwencji współcześni glottodydaktycy znacznie częściej wypowiadają się na temat składników kompetencji komunikacyjnej, niż procesu kształtowania się tej kompetencji u poszczególnych użytkowników języka i to pomimo, że epistemologicznie specyficzne dla glottodydaktyki podejście podmiotowe powinno wzmacniać ukierunkowanie na zindywidualizowany proces rozwijania kompetencji.

Należy pamiętać, że współczesna glottodydaktyka to dziedzina poznania, która staje się coraz mniej jednolita paradygmatycznie i metodologicznie, czemu towarzyszy pewnego rodzaju "rozproszenie koncepcyjne” (zob. Wilczyńska, 2010) i wielokierunkowość podejmowanych badań. Ilustruje to współwystępowanie na gruncie współczesnej glottodydaktyki chociażby takich paradygmatów, jak: wspomniana już dydaktyka autonomizująca (Wilczyńska, 2002) i paradygmat mediacyjny (Sujecka-Zając, 2016). Co istotne, pomimo że badania glottodydaktyczne wpisujące się w oba te paradygmaty odnoszą się do współdziałania osoby uczącej się i nauczającej oraz zakładają podmiotowe traktowanie użytkownika $\mathrm{J} 2$, to $\mathrm{z}$ racji ich odmiennego ukierunkowania para dygmatycznego i nieprzystającej do siebie terminologii trudno byłoby doprowadzić do konsolidacji wiedzy konstruowanej w ramach tych badań.

Jednocześnie W. Wilczyńska i A. Michońska-Stadnik (2010) piszą o trzech zasadniczych podejściach metodologicznych w glottodydaktyce: ilościowym, jakościowym, mieszanym (hybrydowym) i zwracają uwagę na komplementarność dwóch pierwszych orientacji, gdyż podejście jakościowe służy pełniejszemu uchwyceniu danego zjawiska w celu lepszego zrozumienia jego istoty, uwarunkowań i dynamiki, podczas gdy podejście ilościowe nastawione jest na weryfikację konkretnych związków i zależności. Warto podkreślić, że w przypadku glottodydaktycznego obszaru międzykulturowości, jak wskazuje na to analiza ponad stu publikacji polskich specjalistów dokonana przez T. Roga (2016), głównymi technikami zbierania danych są wywiady, obserwacje lekcji i ankiety samooceny oraz analizy programów nauczania i podręczników. Z pewnością są to techniki najbardziej popularne ze względu na ich poręczność i dostępność użycia, ale uzyskane w ten sposób informacje nie pozwalają w pełni uchwycić dynamiki procesu rozwijania międzykulturowej kompetencji komunikacyjnej u poszczególnych osób, jak i jej przejawów w konkretnych sytuacjach komunikacyjnych. Dlatego warto byłoby pozyskiwać dane również poprzez nagrywanie działań komunikacyjnych osób uczących się i nauczających J2 i dokonywać ich analizy w ramach zastosowania metody analizy dyskursu lub analizy konwersacyjnej (por. Nowicka, 2016). 
Tymczasem w pedagogice mamy do czynienia nie tylko z wieloparadygmatycznością samej dyscypliny, ale i z dużo większą skalą interpretacji oraz dopuszczalnych - a wręcz wymaganych w określonych kontekstach badawczych - empirycznych metod badań. Dla przykładu, J. Nikitorowicz (2003: 200) definiuje holistyczną koncepcję procesu edukacji międzykulturowej na gruncie pedagogiki jako opartą na paradygmacie wspótistnienia, który zakłada otwartość, życzliwość, tolerancję i dialog oraz twórcze kreowanie własnej tożsamości społeczno-ekonomicznej i kulturowej. Pedagogika międzykulturowa, jako jedna z perspektyw pedagogiki ogólnej, operuje w ramach paradygmatów zdecydowanie interpretatywnych, „rozumiejących”, subiektywistycznych i humanistycznych, w których dominuje jakościowa analiza celów poznawczych i badania. $Z$ kolei w badaniach wykorzystuje się takie metody jak: badania w działaniu (action research), studium przypadku (case study), fenomenografia, analiza wywiadów lub opis zdarzenia krytycznego.

Odrębność lub transdyscyplinarność paradygmatów, w jakich sytuują się empiryczne działania badawcze i refleksje teoretyczne w obu analizowanych dyscyplinach, uwidacznia się wyraźniej na tle charakterystycznych dla nich celów poznawczych. W tabeli 2 . zestawiamy ze sobą przykładowe cele poznawcze badań realizowanych w obu dyscyplinach.

\begin{tabular}{|c|c|}
\hline $\begin{array}{l}\text { Cele poznawcze badania } \\
\text { i/lub refleksji naukowej w glottodydaktyce }\end{array}$ & $\begin{array}{l}\text { Cele poznawcze badania } \\
\text { i/lub refleksji naukowej } \\
\text { w pedagogice międzykulturowej }\end{array}$ \\
\hline $\begin{array}{l}\text { Za cel poznawczy uważa się dokonanie spójnej } \\
\text { refleksji naukowej, pozwalającej na lepsze zro- } \\
\text { zumienie zjawiska międzykulturowości z per- } \\
\text { spektywy glottodydaktyki, co w dalszej kolejno- } \\
\text { ści pozwoli również na konkretne aplikacje o } \\
\text { charakterze dydaktycznym (Wilczyńska, 2005). }\end{array}$ & $\begin{array}{l}\text { Celem poznawczym jest, przykładowo, konstruk- } \\
\text { cja paradygmatu współistnienia jako modelu } \\
\text { edukacji międzykulturowej, wyjaśnienie zjawi- } \\
\text { ska edukacji międzykulturowej w ścisłym powią- } \\
\text { zaniu z uwarunkowaniami środowiskowymi i kul- } \\
\text { turowymi, aktywnością własną wychowanków i } \\
\text { instytucji oraz przedstawienie procesu edukacji } \\
\text { w szerokim kontekście kulturowo-społeczno-po- } \\
\text { litycznym; wyjaśnienie aspektów budowania } \\
\text { tożsamości, roli tradycji, wolności, tolerancji, } \\
\text { operacjonalizacja pojęć dominacji i przynależno- } \\
\text { ści kulturowej, formuły społeczeństwa wielokul- } \\
\text { turowego opartego na godności każdej jednostki } \\
\text { (Nikitorowicz 2003, 2009). }\end{array}$ \\
\hline
\end{tabular}

Tabela 2: Przykładowe cele poznawcze w glottodydaktyce i pedagogice (opracowanie własne)

Porównując chociażby te wybrane cele poznawcze w glottodydaktyce i pedagogice, zauważamy, że obie dyscypliny dążą do lepszego zrozumienia społecznego funkcjonowania międzykulturowego jednostek, z tą różnicą, że w glottodydaktyce jest ono ściślej (co nie znaczy wyłącznie) powiązane z rozwijaniem kompetencji 
komunikacyjnej w J-K2 i jej aplikacyjną, dydaktyczno-komunikacyjną stroną. Cele poznawcze pedagogiki, nie ignorując językowej strony dialogu, koncentrują się z kolei silniej na aksjologicznych i socjalizacyjnych procesach akulturacji lub wykluczeń społecznych i w tym sensie dotyczą wyższego poziomu ogólności.

Warto w kontekście powyższego różnicowania przywołać także funkcjonujące w pedagogice paradygmaty iluzoryczny i schizoidalny (zob. Jaskuła i Korporowicz, 2017) jako elementy nowej zupełnie typologii wynikającej ze zmian w systemach komunikowania się, w tym międzykulturowego. Trudno określić na obecnym etapie ich konstytuowania się w nauce, co miałoby być celem poznawczym odnoszącym się, np. do iluzoryczności celów poznawczych i badań w omawianych tu dyscyplinach. Niewątpliwie jednak, jako że zarówno glottodydaktyka, jak i pedagogika, interesują się komunikacją społeczną, należy przyjąć, że będą one musiały uwzględnić zmiany w zakresie formy, kształtu, obranego medium a przez to zmieni się efektywność i kierunek oddziaływania naukowego lub dydaktycznego. Zmiana ta podążać będzie raczej w kierunku demokratyzacji, przyspieszenia i usieciowienia (networking) komunikacji, aniżeli w stronę tradycyjnych dotąd jej osadzeń w strukturalistycznych oraz interpretatywno-humanistycznych paradygmatach. Czy zatem, w swej skrajnej postaci, paradygmat iluzoryczny nie stanie się wkrótce punktem odniesienia w badaniach nad językiem i komunikacją?

Poszukując tymczasem wspólnego paradygmatu dla glottodydaktyki i pedagogiki międzykulturowej na obecnym etapie ich rozwoju, warto przytoczyć paradygmat złożoności zaproponowany przez E. Morina (2008), którego zdaniem wszelka innowacja ma miejsce na granicy różnych dyscyplin. W przypadku, gdy podejście międzykulturowe zakłada, że ważniejsze od uzyskiwania pewnych odpowiedzi jest stawianie pytań i dystansowanie się od własnych etnocentrycznych wyobrażeń, przekonanie Morina, że postęp dokonuje się w złożoności i niepewności, a nie na drodze wypracowania niepodważalnych prawd i uniwersalnych rozwiązań mogłoby być punktem odniesienia zarówno dla glottodydaktyków, jak i pedagogów. Co więcej, dostrzegamy spójność pomiędzy paradygmatem złożoności Morina (2008), a paradygmatem współistnienia Nikitorowicza (2003) jako modelu edukacji międzykulturowej w ujęciu holistycznym, która uwzględnienia jednocześnie dokonujące się procesy transformacji, modernizacji, globalizacji i integracji kultury, stawiając jednostkom, grupom i społeczeństwom coraz to inne wyzwania. Sama koncepcja edukacji międzykulturowej Nikitorowicza ewaluowała zresztą w czasie i w swoich ostatnich publikacjach (zob. Nikitorowicz, 2017) pedagog ten łączy kreowanie paradygmatu współistnienia różnych kultur z zapewnieniem członkom kształtujących się społeczeństw wielokulturowych możliwości kreowania tożsamości ponadnarodowej, międzykulturowej i transkulturowej. Przestrzega tym samym przed 
ideologizacją własnego narodu w państwowej polityce edukacyjnej i opowiada się za tzw. heterologią ${ }^{4}$, która mogłaby przyczynić się do kształtowania postaw poczucia wspólnoty gatunku ludzkiego ponad wszelkimi różnicami.

Otwartym pozostaje pytanie, czy w przypadku glottodydaktyki, której przedmiot poznania jest już sam w sobie złożony, osadzony społecznie i kulturowo, a jednocześnie ukierunkowany podmiotowo, nie chodzi obecnie bardziej o zdefiniowanie glottodydaktycznych konfiguracji czynników, jakie wpływają na osobisty rozwój lub stagnację kompetencji międzykulturowej osób uczących się J-K2 w konkretnych kontekstach kształcenia językowego. Nie mniej ważne dla glottodydaktyki byłoby modelowanie kompetencji międzykulturowej różnojęzycznych użytkowników języka. Punktem wyjścia mogłyby być $w$ tym przypadku np. badania nad zależnościami pomiędzy deklarowaną tożsamością kulturowo-językową badanych, a ich deklaracjami w zakresie postrzegania przedstawicieli innych kultur i języków, przy czym badania dotyczące deklaracji powinny oczywiście zostać uzupełniane badaniami na poziomie działań komunikacyjnych. Tym samym, jak widać, wskazana byłaby triangulacja metodologiczna, sugerująca już per se konieczność korzystania z obu paradygmatów: subiektywistycznego (dla badania deklaracji) i obiektywistycznego (dla zbadania działań językowych i ich efektów społecznych).

\subsection{Cele kształcenia - inne czy tożsame dla obu dyscyplin?}

Ukierunkowaną aplikacyjnie odsłonę naszej metaanalizy nad spójnością lub rozbieżnością glottodydaktycznego obszaru międzykulturowości oraz pedagogiki międzykulturowej stanowią formułowane przez badaczy obu dyscyplin cele kształcenia, których przykłady prezentuje poniższa Tabela 3.

\begin{tabular}{|l|l|}
\hline Cele kształcenia w nauczaniu-uczeniu się J-K2 & $\begin{array}{l}\text { Cele kształcenia w ramach pedagogiki międzykultu- } \\
\text { rowej }\end{array}$ \\
\hline $\begin{array}{l}\text { - praca nad poczuciem tożsamości określonych osób i } \\
\text { ich sposobu jej przeżywania jako baza dla rozwoju in- } \\
\text { dywidualnej kompetencji (inter)kulturowej Wilczyń- } \\
\text { ska, 2005); }\end{array}$ & $\begin{array}{l}\text { - nauczenie i prowadzenie dialogu kultur, a przede } \\
\text { wszystkim dialogu kultury lokalno-regionalnej z konty- } \\
\text { nentalno-planetarną; } \\
\text { - otwarcie ludzi na siebie, a także zauważenie i podję- } \\
\text { cie próby zrozumienia inności kulturowej poprzez ak- } \\
\text { ceptację i zrozumienie własnej jest priorytetem, dzięki } \\
\text { któremu można doświadczyć inności, nie rezygnując z } \\
\text { własnych idei i wartości (Nikitorowicz, 2003); }\end{array}$ \\
\hline
\end{tabular}

\footnotetext{
${ }^{4}$ Heterologię definiuje J. Nikitorowicz (2017: 18) jako ideę, zasadę życia społecznego i postawę wyrażoną wobec innego, która opiera na otwartości, a niweluje etnocentryzm i socjocentryzm, negatywne wyobrażenia Innego, megalomanię, ksenofobię, niechęć, lęki, wrogie nastawienie do Innych, odmiennych rasowo, religijnie czy etnicznie.
} 
Międzykulturowość jako przestrzeń dla transdyscyplinarnej metaanalizy...

\begin{tabular}{|c|c|}
\hline $\begin{array}{l}\text { - rozwój kompetencji międzykulturowej oparty na } \\
\text { podmiotowym uczestnictwie w kulturze, ze szczegól- } \\
\text { nym uwzględnieniem dynamiki teorii subiektywnych } \\
\text { dotyczących natury inności kulturowej i przy jednocze- } \\
\text { snym uwzględnieniu autopoznawczego potencjału } \\
\text { międzykulturowości (Torenc, 2007); }\end{array}$ & $\begin{array}{l}\text { - asymilowanie mniejszości z większością, zaznajamia- } \\
\text { nie z kulturą dominującą na danym terenie (język, hi- } \\
\text { storia, kultura) - przy zachowaniu poprawności poli- } \\
\text { tycznej; }\end{array}$ \\
\hline $\begin{array}{l}\text { - rozwój kompetencji międzykulturowej, której moto- } \\
\text { rem rozwoju jest osobista kompetencja uczeniowa; ta } \\
\text { ostatnia ukierunkowuje rozwijanie wiedzy, umiejętno- } \\
\text { ści i postaw o charakterze międzykulturowym, a jej } \\
\text { wyznacznikami są świadomość (meta)kulturowa, która } \\
\text { pozwala m.in. na kontekstualizację i kategoryzację fak- } \\
\text { tów i zjawisk (między)kulturowych oraz wrażliwość ję- } \\
\text { zykowo-komunikacyjną, której przejawem jest m.in. } \\
\text { selekcja nowej wiedzy i umiejętności oraz ocena ich } \\
\text { przydatności w rozbudowie całościowej osobistej } \\
\text { kompetencji komunikacyjnej (Orchowska, 2008); }\end{array}$ & $\begin{array}{l}\text { - wychowanie ku tolerancji, odrzucenie rasizmu i } \\
\text { uwrażliwienie na problem stygmatyzacji, uprzedzeń, } \\
\text { stereotypizacji (w tym poprzez język); } \\
\text { - uwrażliwienie mniejszości na sposoby i motywację } \\
\text { do upominania się o swoje prawa, strukturalne } \\
\text { krzywdy, poprawę warunków społecznych i ekono- } \\
\text { micznych (za: Rada Europy, } 2003 \text { w: Nikitorowicz, } \\
\text { 2009); }\end{array}$ \\
\hline $\begin{array}{l}\text { - rozwój świadomości metajęzykoznawczej jako bazy, } \\
\text { dzięki której może zachodzić rozpoznanie i określenie } \\
\text { inności będące podstawą dalszych procesów poznaw- } \\
\text { czych (Karpińska-Musiał, 2015: 126), przy czym „poro- } \\
\text { zumienie komunikacyjne w kontekście międzykulturo- } \\
\text { wym jest wciąż wizją otwartą, zadaniem, którego roz- } \\
\text { wiązanie nie jest jednorazowym wydarzeniem o za- } \\
\text { mkniętej strukturze” (ibidem, 2015: 127). }\end{array}$ & $\begin{array}{l}\text { - przygotowanie ludzi do zgodnego współżycia w spo- } \\
\text { łeczeństwie zróżnicowanym, wielokulturowym (Niki- } \\
\text { torowicz, 2009). }\end{array}$ \\
\hline
\end{tabular}

Tabela 3: Cele kształcenia w zakresie kompetencji międzykulturowej w ujęciach glottodydaktyków i pedagogów (opracowanie własne)

O ile podejście międzykulturowe w glottodydaktyce jest skoncentrowane w warstwie dydaktycznej na rozwijaniu kompetencji międzykulturowej osób uczących się jako integralnej części ich osobistego rozwoju, w tym uświadamianiu sobie własnej tożsamości, to już perspektywa zadaniowa z Europejskiego Systemu Opisu Kształcenia Językowego (Rada Europy, 2003) jest ukierunkowana na wspólne działanie i tworzenie tzw. współkultury, obejmującej wspólne koncepcje, jakie są podzielane ze względu na lub poprzez wspólne działanie. Tym samym staje się ona bliższa perspektywie pedagogicznej, która - w celach kształcenia - kładzie nacisk na tożsamość konstruowaną społecznie, relacyjnie, wobec Drugiego (Innego) i w silnie określonym kontekście społeczno-kulturowym oraz historycznym. Jak precyzuje Ch. Puren (netografia), koncepcje te (elementy współkultury) mogą być odziedziczone po przodkach, a zatem stać się przedmiotem mniej lub bardziej świadomego przyjęcia kultury pochodzenia (w sposób transmisyjny), mogą być również negocjowane lub wypracowywane razem poprzez tworzenie czegoś oryginalnego lub na drodze przenikania się różnych kultur ( $w$ duchu analizy transakcyjnej). Naszym zdaniem tak duża swoboda w interpretowaniu pojęcia współkultury może ułatwić dialog międzykulturowy, ale również pozwala wykroczyć poza jego ramy. Tym samym, może 
ono być definiowane jako kolejne pojęcie transwersalne, które byłoby operacyjne w szeroko rozumianej w edukacji międzykulturowej. Edukacja taka powinna jednak uzupełniać kształcenie językowe, a nie je zastępować.

\section{Podsumowanie}

Podsumowując refleksję nad transdyscyplinarnością glottodydaktycznego obszaru międzykulturowości i pedagogiki międzykulturowej na podstawie obranych kryteriów pojęć, paradygmatów i celów kształcenia, pragniemy przede wszystkim podkreślić fakt, że na obecnym etapie rozwoju obu dyscyplin możliwe jest już konstruowanie funkcjonalnych pojęć transwersalnych odnoszących się do międzykulturowości w obu dyscyplinach. W najszerszym ujęciu, przykładami takich pojęć są np. kultura oraz tzw. współkultura, a zmierza ku takiej klasyfikacji kompetencja interkulturowa. Co więcej, pojęcie współkultury, funkcjonujące obecnie głównie na gruncie glottodydaktyki mogłoby zyskać na funkcjonalności dydaktycznej dzięki jego metaanalizie transdyscyplinarnej i uwzględnieniu w niej np. założeń nowej socjologii komunikacji międzykulturowej. Szczególnego znaczenia nabrałoby ono wobec paradygmatów operacyjnych dla cyfrowej komunikacji społecznościowej i mediatyzacji komunikacji międzykulturowej, takich jak iluzoryczny lub schizoidalny.

Natomiast badania nad dynamiką rozwoju kompetencji międzykulturowej w danym kontekście kształcenia językowego wymagają nadal modelowania uwzględniającego jego specyfikę, w tym wzięcie pod uwagę uwarunkowań właściwych dla konkretnych osób, użytkowników języka rodzimego lub obcego. Innymi słowy, pojęcie to może być operacyjne, jeśli będziemy je rozpatrywać w badaniu konkretnych zakresów aktywności u osób uczących się i nauczających J-K2 oraz u użytkowników języka, funkcjonujących w danej rzeczywistości społeczno-kulturowej. Czym innym jest np. mediacja międzykulturowa zapośredniczona przez nauczyciela pracującego z dziećmi, a czym innym rola mediatora międzykulturowego, jaką ma do spełnienia nauczyciel akademicki wśród studentów neofilologii. Jeszcze czymś innym jest mediacja i edukacja międzykulturowa (w tym językowa) prowadzona w zróżnicowanym etnicznie społeczeństwie wielokulturowym.

Konkludując, podjęta w niniejszym artykule refleksja nad transdyscyplinarnością obu dyscyplin paradoksalnie zrodziła w nas przekonanie o konieczności większego dopracowania aparatu pojęciowego i zdefiniowania paradygmatów w ich ujęciu najpierw dyscyplinarnym, a potem inter- i transdyscyplinarnym. Konieczna jest zatem świadomość specyfiki epistemologicznej danej nauki, aby mogła ona wejść w dialog transdyscyplinarny, wzbogacający ją w wymiarze konceptualnym, paradygmatycznym i dydaktycznym. Na obecnym etapie 
rozwoju tożsamości naukowej opisywanych dyscyplin bardziej zasadne wydają się być badania nad międzykulturowością ukierunkowane nadal interdyscyplinarnie, niż dążenie do zbyt szeroko zakrojonej transdyscyplinarności. Interdyscyplinarność pozwala bowiem badaczom na otwieranie się na nowe obszary i perspektywy badawcze, przy jednoczesnym wyraźnym uwzględnianiu specyfiki reprezentowanej przez nich dyscypliny. Jest to szczególnie ważne w przypadku tak szeroko definiowanych obszarów poznania naukowego jak glottodydaktyczny obszar międzykulturowości i pedagogika międzykulturowa. Przyjęcie perspektywy interdyscyplinarnej stwarza szansę na to, aby poszerzeniu pola badawczego glottodydaktyki poprzez uwzględnienie (meta)poznawczych doświadczeń pedagogiki towarzyszyło pogłębienie teoretyczne podejmowanych problemów badawczych, a do rozwoju pedagogiki międzykulturowej dodany został aspekt dyskursywny i dialogiczny rozpatrywany z perspektywy rozwoju kompetencji komunikacyjnej. Sama natomiast kompetencja międzykulturowa (obrana tu jako przykład pojęcia poddanego metaanalizie porównawczej) zyskałaby bez wątpienia na operacyjności, gdyby była definiowana i rozwijana przy uwzględnieniu jej konkretnych wyznaczników, zależnych od specyficznego kontekstu kształcenia. Konteksty kształcenia bowiem będą różnić się zawsze zależnie od przyjętych celów kształcenia, a te, mimo znaczących podobieństw w obszarze międzykulturowości, są jednak profilowane nieco inaczej w obu omawianych dyscyplinach naukowych.

\section{BIBLIOGRAFIA}

Ablewicz K. (2003), Teoretyczne i metodologiczne podstawy pedagogiki antropologicznej. Studium sytuacji wychowawczej. Kraków: Wydawnictwo Uniwersytetu Jagiellońskiego.

Aleksandrowicz-Pędich L. (2005), Międzykulturowość na lekcjach języków obcych. Białystok: Wydawnictwo Uniwersytetu w Białymstoku.

Byram M., Risager K. (1999), Language Teachers, Politics and Cultures. Clevedon: Multilingual Matters.

Bourse M. 2008, Interculturel ou multiculturel : itinéraires sémantiques et évolution idéologiques (w) „Signes, discours, sociétés”. Online: [DW 08.01.2019]

Braidotti R. (2014), Po człowieku. Warszawa: PWN.

Chrzanowska-Kluczewska E. (2016), Konsiliencja, czyli o porozumieniu między naukami w trzecim tysiq̨cleciu (w) „Półrocznik Językoznawczy Tertium. Tertium Linguistic Journal", nr 1 (1\&2), str. 40-49.

Dakowska M. (2010), Glottodydaktyka jako nauka (w) „Lingwistyka Stosowana", nr 3, str. 71-86.

Dakowska M. (2014), O rozwoju dydaktyki języków obcych jako dyscypliny naukowej. Warszawa: Wydawnictwo Uniwersytetu Warszawskiego. 
Folkierska A. (1990), Pytanie o pedagogikę. Warszawa: Wydawnictwa Uniwersytetu Warszawskiego.

Jaroszewska A. (2014), O glottodydaktyce słowami glottodydaktyków (w) „Języki Obce w Szkole", nr 4, str. 52-66.

Jaskuła S., Korporowicz L. (2017), Współczesne paradygmaty dialogu (w) „Edukacja Humanistyczna”, nr 2 (37), str. 33-43.

Karpińska-Musiał B. (2015), Międzykulturowość w glottodydaktyce. O zwiqzku świadomości metajęzykoznawczej z kompetencjq międzykulturowq $w$ akademickim kształceniu nauczycieli języków obcych. Gdańsk: Wydawnictwo Uniwersytetu Gdańskiego.

Kita M. (2012), Razem: konsiliencja, interdyscyplinarność, transdyscyplinarność (w) Kita M., Ślawska M. (red.), Transdyscyplinarność badań nad komunikacją medialną. Katowice: Wydawnictwo Uniwersytetu Śląskiego, str. 11-30. Komorowska H. (2010), Dydaktyka języków obcych a nauki społeczne (w) Wąsik Z., Wach A. (red.), Heteronomie glottodydaktyki: Domeny, pogranicza i specjalizacje nauczania języków obcych. Poznań: Instytut Filologii Angielskiej, str. 51-62.

Kwieciński Z. (2011), Spory o paradygmat w pedagogice (w) Kwieciński Z. (red.), Cztery i pół. Preliminaria - laminaria -varia. Wrocław: Wydawnictwo Naukowe Dolnośląskiej Szkoły Wyższej, str. 370-376.

Mikułowski-Pomorski J. (2006), Jak narody porozumiewajq się ze sobq w komunikacji międzykulturowej $i$ komunikowaniu medialnym. Kraków: Universitas.

Morin E. (2008), La Méthode. Paris: Seuil.

Narcy-Combes M.-F. (2018), La transdisciplinarité dans l'intervention en linguistique appliquée (w) „Études de Linguistique Appliquée”, nr 190, str. 183-193.

Nikitorowicz J. (2003), Kreowanie tożsamości dziecka. Wyzwania edukacji międzykulturowej. Gdańsk: Gdańskie Wydawnictwo psychologiczne.

Nikitorowicz J. (2009), Edukacja regionalna i międzykulturowa. Warszawa: Wydawnictwa Akademickie i Profesjonalne.

Nikitorowicz J. (2017), Polityka edukacyjna w kontekście potrzeby nabywania kompetencji międzykulturowych (w) „Pogranicze. Studia Społeczne”, nr 30, str. 7-19.

Nikitorowicz J., Sobecki M., Danilewicz W., Muszyńska J., Misiejuk D., Bajkowski T. (2013), Kompetencje do komunikacji międzykulturowej w aspekcie wielokulturowości regionu i procesów migracyjnych. Warszawa: Wydawnictwo Akademickie Żak.

Niżegorodcew A. (2009), Dwie tradycje badawcze w językoznawstwie stosowanym dotyczqcym języka drugiego (w) „Neofilolog”, nr 32, str. 7-16. Nowicka A. (2016), Ethnic Categorization in Interviews in English as Lingua Franca. Frankfurt am Main: Peter Lang Edition. 
Orchowska I. (2008), La formation interculturelle des futurs enseignants de FLE dans le contexte universitaire polonais. Kraków: FLAIR.

Orchowska I. (2019, w opracowaniu), O autonomii przedmiotu poznania polskiej dydaktyki 22 z perspektywy metaglottodydaktycznej. Od syntezy do metaanalizy dyskursu (meta)glottodydaktycznego. Poznań.

Pfeiffer W. (2001), Nauka języków obcych. Od praktyki do praktyki. Poznań: Wagros. Pfeiffer W. (2010), Esej o przywracaniu równowagi w glottodydaktyce polskiej (w) Wąsik Z., Wach A. (red.), Heteronomie glottodydaktyki: Domeny, pogranicza i specjalizacje nauczania języków obcych. Poznań: Instytut Filologii Angielskiej, str. 75-85.

Puppel S. (2007), Interlingwalizm czy translingwalizm? Interkomunikacja czy transkomunikacja? Uwagi w kontekście wspótistnienia języków naturalnych w ramach globalnej wspólnoty kulturowo-językowo-komunikacyjnej (w) Puppel S. (red.), Społeczeństwo-kultura-język. W stronę interakcyjnej architektury komunikacji. Poznań: Katedra Ekokomunikacji UAM, str. 79-94.

Puren Ch. (2019), L'interculturel, une composante parmi d'autres de la compétence culturelle (w) „Neofilolog”, nr 52/2, str. 213-226.

Rada Europy (2001/2003), Europejski system opisu kształcenia językowego: uczenie się, nauczanie, ocenianie. Warszawa: CODN.

Róg T. (2016), Glottodydaktyczne obszary badań nad kompetencja międzykulturowq (w) „Neofilolog", nr 47/2, str. 133-152.

Sitaram Roy K., Cogdell T. (1976), Foundations of Intercultural Communication. Columbus: Charles E. Merrill Publishing Company.

Sujecka-Zając J. (2016), Kompetentny uczeń na lekcji języka obcego. Wyzwania dla glottodydaktyki mediacyjnej. Lublin: Werset.

Szlosek F. (2001), Kompetencje czy kwalifikacje zawodowe nauczycieli akademickich? (w) Sałata E. (red.) Kompetencje zawodowe nauczycieli a problemy reformy edukacyjnej. Radom: Wydawnictwo ITE

Talaś M., Galanciak S. (red.) (2018), Cyberprzestrzeń, Człowiek, Edukacja. Mistrz i uczeń w cyberprzestrzeni. Kraków: Oficyna Wydawnicza „Impuls”.

Torenc M. (2007), Nauczanie międzykulturowe - implikacje glottodydaktyczne. Wrocław: Oficyna Wydawnicza ATUT.

Wilczyńska W. (2002a), Podmiotowość i autonomia jako wyznaczniki osobistej kompetencji komunikacyjnej (w) Wilczyńska W. (red.), Autonomizacja w dydaktyce języków obcych. Doskonalenie się w komunikacji ustnej. Poznań: Wydawnictwo Naukowe UAM, str. 51-67.

Wilczyńska W. (2002b), Słowniczek najważniejszych pojęć dotyczq̨cych autonomizacji (w) Wilczyńska W. (red.), Autonomizacja w dydaktyce języków obcych. Doskonalenie się w komunikacji ustnej. Poznań: Wydawnictwo Naukowe UAM, str. 319. 
Wilczyńska W. (2005), Czego potrzeba do udanej komunikacji interkulturowej ? (w) Mackiewicz M. (red.), Dydaktyka języków obcych a kompetencja kulturowa i kompetencja międzykulturowa. Poznań: Wydawnictwo Wyższej Szkoły Bankowej, str. 15-26.

Wilczyńska W. (2010), Obszary badawcze glottodydaktyki (w) „Neofilolog”, nr 34, str. 21-35.

Wilczyńska W. (2016), Pojęcie kompetencji komunikacyjnej i jego przydatność poznawcza dla glottodydaktyki (w) Jaroszewska, A., Karpeta-Peć, B., Smuk, Maciej., Sobańska, J. i Sujecka-Zając J. (red.), Wielojęzyczność $i$ międzykulturowość na lekcji języka obcego - między teoriq a praktykq nauczania. Warszawa: Wydawnictwo UW, str. 95-110.

Wilczyńska W., Michońska-Stadnik A. (2010), Metodologia badań w glottodydaktyce. Kraków: Avalon/Flair.

Wilczyńska W., Mackiewicz M., Krajka J. (2019), Komunikacja interkulturowa. Wprowadzenie. Poznań: Wydawnictwo Naukowe UAM.

Zając J. (2010), Glottodydaktyka w ujęciu epistemologicznym (w) „Neofilolog” nr 34, str. 37-48.

\section{NETOGRAFIA}

Piaget J. (1972), L'épistémologie des relations interdisciplinaires. Online: http://www.fondationjeanpiaget.ch/fjp/site/textes/VE/jp72_epist_rel at_interdis.pdf [DW 15.01.2019]

Puren Ch. (2011), Composantes sémantiques du concept de conception [de I'action] Online: https://www.christianpuren.com/biblioth\%C3\%A8que -de-travail/045/ [DW 14.02.2019] 